\title{
MENINGKATKAN PERILAKU ASERTIF PESERTA DIDIK MELALUI LAYANAN BIMBINGAN KELOMPOK MENGGUNAKAN TEKNIK SOSIODRAMA (BERMAIN PERAN) DI SMAN 1 MALIKU
}

\author{
Lusihana \\ SMA Negeri 1 Maliku
}

\begin{abstract}
ABSTRAK
Penelitian ini bertujuan untuk meningkatkan perilaku asertif peserta didik melalui bimbingan kelompok menggunakan teknik sosiodrama. Perilaku asertif adalah kemampuan untuk mengkomunikasikan apa yang diinginkan, dirasakan, dan dipikirkan kepadaorang lain secara jujur dan terbuka dengan tetap menghormati hak pribadi dan orang lain. Peserta didik yang mampu menerapkan perilaku asertif dalam kehidupan sehari-hari akan memiliki ketrampilan sosial yang dibutuhkannya dalam pergaulan. Rancangan penelitian yang digunakan adalah menggunakan metode Deskriptif Kualitatif. Teknik pengumpulan data yang digunakan adalah observasi, wawancara, dan dokumentasi. Tindakan yang dilaksanakan dalam penelitian ini adalah pemberian layanan bimbingan kelompok teknik sosiodrama, yaitu pemberian layanan bimbingan kepada sekelompok individu dengan cara bermain peran guna memecahkan masalah yang dialaminya yaitu kurangnya berperilaku asertif. Hasil penelitian menunjukkan bahwa bimbingan kelompok teknik sosiodrama dapat meningkatkan perilaku asertif siswa Kelas X SMAN 1 Maliku. Melalui sosiodrama, siswa dapat secara langsung merasakan manfaat layanan yaitu dapat mempraktekkan cara berperilaku asertif sehingga keterampilan tersebut dapat diterapkan dalam kehidupan seharihari. Keberhasilan layanan bimbingan kelompok teknik sosiodrama menunjukkan bahwa sosiodrama tepat digunakan dalam meningkatkan perilaku asertif siswa. Perubahan sikap yang terjadi setelah mengikuti sosiodrama adalah sebagian besar peserta didik mampu menerapkan perilaku asertif dalam kehidupan sehari-hari terutama dalam lingkungan sosial teman sebayanya, sehingga peserta didik merasakan manfaat dari perubahan tingkah lakunya, misalkan ada perubahan beberapa nilai karena peserta didik dapat mengumpulkan tugas tepat waktu dan dapat belajar dengan cukup, rasa percaya dalam dirinya meningkat, peserta didik lebih peka dalam memahami apa yang diinginkan oleh dirinya sendiri dan apa yang tidak diinginkan oleh dirinya, apa yang bermanfaat bagi dirinya sendiri dan apa yang tidak bermanfaat. Selain itu peserta didik lebih aktif menyuarakan pendapat ketika rapat organisasi, dan mampu untuk berkata tidak apabila tidak setuju dengan hal-hal yang dibicarakan ketika rapat dengan mempertimbangkan perasaan teman sebayanya.
\end{abstract}

Kata Kunci: perilaku asertif, bimbingan kelompok, sosiodrama

\section{PENDAHULUAN}

Istilah Adolescence atau remaja berasal dari kata latin adolescere (kata Belanda, adolescentia yang berarti remaja) yang berarti tumbuh atau tumbuh menjadi dewasa (dalam Hurlock, 1999). Istilah adolescence, seperti yang dipergunakan saat ini mempunyai arti yang luas mencakup kematangan mental, emosional, spasial dan fisik. Dalam tugas perkembangannya remaja akan melewati beberapa fase dengan berbagai tingkat kesulitan permasalahan, sehingga dengan mengetahui tugas- tugas perkembangannya remaja dapat mencegah konflik yang ditimbulkannnya dalam keseharian tujuannya agar tidak salah persepsi dalam menangani permasalahan tersebut. Pada masa perkembangan itu juga 
Jurnal Inovasi BK, Volume 2, Nomor 1 Juni 2020

kondisi psikis remaja sangat labil karena masa ini merupakan fase pencarian jati diri. Fatimah (2010) menjelaskan bahwa kehidupan pribadi seseorang meliputi berbagai aspek, antara lain aspek emosional, sosial psikologis, sosial budaya, dan kemampuan intelektual yang terpadu dengan faktor lingkungan dalam kehidupannya.

Salah satu tugas perkembangan pada masa remaja adalah membuat suatu perubahan besar dalam sikap dan pola perilaku. Salah satu perubahan yang terjadi adalah perubahan sosial. Perubahan sosial pada masa remaja merupakan perubahan yang sulit dilakukan. Hubungan teman sebaya memiliki perubahan yang penting dalam masa remaja. Tujuan dari hubungan teman sebaya adalah agar disukai oleh teman sekelas dan dilibatkan dalam permainan atau percakapan dengan teman sebaya. Menurut Hurlock (1997: 213), untuk mencapai tujuan tersebut remaja harus membuat penyesuain diri terhadap teman sebaya. Dalam kehidupan individu khusunya remaja jika dapat menyesuaikan diri dengan lingkungan sekitar maka ia akan diterima oleh lingkungan sekitarnya. Penyesuaian diri memang sangat dibutuhkan dalam kehidupan sehari- hari tetapi remaja harus mampu membedakan antara baik dan buruk.

Tidak semua manusia dapat menjalankan kehidupannya dengan lancar dan mencapai kebahagiaan. Pada masa remaja terdapat masa sulit, yaitu masa di mana seseorang ditolak dalam suatu kelompok. Mappiare (1982) menyatakan bahwa "penolakan teman sebaya dalam kelompok bagi seorang remaja mempunyai pengaruh yang kuat atau besar terhadap pikiran, sikap, perasaan, perbuatanperbuatan dan penyesuaian diri remaja". Padahal hubungan sosial merupakan kebutuhan dasar manusia untuk dimiliki dan dicintai (belonging and love). Sejalan dengan pendapat Marini, Liza, dan Elvi Andriani (2005) bahwa "tidak semua orang dapat berperilaku asertif, karena asertif bukan bawaan dari lahir. Akan tetapi perilaku yang dapat dipelajari melalui lingkungan. Hal tersebut senada dengan pernyataan Rathus dan Nevis bahwa "perilaku asertif merupakan pola-pola yang dipelajari dari lingkungan sebagai reaksi terhadap situasi sosial dalam kehidupannya". Menurut (Dewi, 2016:1) perilaku asertif yang rendah perlu mendapatkan penanganan agar dapat berkembang dengan baik, karena jika terus dibiarkan dapat menimbulkan dampak yang tidak baik pada kehidupan sehari hari. Seseorang yang dikatakan tidak berperilaku asertif ketika orang tersebut tidak mampu menyatakan perasaanperasaan, kebutuhan-kebutuhan dan gagasan-gagasannya secara tepat, mengabaikan hak-haknya dan membiarkan orang lain melanggar haknya tersebut.

Tugas peserta didik adalah sebagai agent of change di dunia sekolah, harus memiliki sifat yang aktif, mandiri, kreatif, dewasa dalam cara berpikir dan perilakunya. Mereka harus mampu menempatkan diri pada situasi yang tepat, memiliki problem solving yang tepat sasaran. Dalam aktifitas secara umum, mereka pasti akan dituntut untuk bekerjasama, berdiskusi, menghargai, menghormati, dan memahami ide-ide atau pendapat dari lingkungan akademisnya. Menyuarakan aspirasi pada peserta didik membutuhkan sikap yang asertif, baik dalam lingkungan sosial, organisasi, dan kegiatan belajar mengajar dikelas. Kegiatan di kelas sering menuntut peserta didik untuk menyuarakan semua ide pemahamannya terhadap materi yang telah atau sedang dipelajari. Ada beberapa alasan dan situasi yang membuat mereka enggan menyampaikan aspirasi mereka dalam forum kelas atau forum organisasi di sekolah. Mereka lebih memilih bersikap diam karena takut salah, kurang mengerti, atau malu untuk bertanya saat pembelajaran berlangsung.

Literatur menunjukkan pentingnya proses belajar yang aktif, dimana siswa 
terikat dan terlibat dalam proses pembelajaran materi dibanding hanya pasif menerima (Boniecki \& Moore, 2003). Partisipasi siswa di kelas memfasilitasi murid mendapatkan pengetahuan dan mengembangkan kemampuan pemecahan masalah (Murray \& Lang, 1997). Sehingga, penting bagi siswa untuk mengembangkan gaya komunikasi yang baik, yaitu asertif. Asertif adalah perilaku yang memungkinkan seseorang untuk menyampaikan dan bertindak sesuai keinginannya sendiri tanpa kecemasan untuk mengungkap perasaannya secara jujur dan tidak melanggar hak orang lain (DeVito, 2013). Perilaku asertif berdampak pada efektivitas seseorang dalam situasi sosial, dimana dampak positif ini dapat hilang jika seseorang memiliki kecemasan dalam situasi sosial (Gambril, 2006).

Ketidakmupan peserta didik dalam menerpakan perilaku asertif tidak hanya terjadi dalam proses belajar saja. Dalam lingkungan sosial pertemanannya peserta didik sering kali merasa tidak berdaya untuk menolak ajakan-ajakan teman sebayanya untuk nongkrong atau sekedar berkumpulkumpul dengan temannya. Tidak jarang mereka merasa hal itu bertentangan dengan keinginannya, karena diwaktu yang bersamaan ada beberapa tanggungan tugas yang harus mereka selesaikan, karena sudah mendekai deadline untuk pengumpulan tugas. Hal ini mereka lakukan agar mereka dapat diterima di lingkungan teman sebayanya dan tidak dikeluarkan oleh gang atau klik mereka. Mereka merasa bingung bagaimana harus menentukan sikap agar mereka mampu mengerjakan tugas dengan tepat waktu, namun mereka juga dapat selalu diterima oleh teman sebayanya. Menurut Soendjojo (Novalia dan Dayakisni, 2013), individu yang memiliki sikap asertif yang rendah memiliki banyak ketakutan irasional yang meliputi sikap menampilkan perilaku cemas dan tidak mempunyai kemampuan untuk mempertahankan hakhak pribadinya.

Menyikapi permasalahan yang ada tersebut, maka perilaku asertif perlu diterapkan dan ditingkatkan oleh peserta didik dalam upaya mewujudkan keterampilan sosial. Penelitian ini bertujuan untuk memaparkan, menjelaskan dan menganalisis layanan bimbingan kelompok dengan teknik sosiodrama (bermain peran) sebagai sarana latihan peserta didik dalam meningkatkan perilaku asertif. Penelitian ini difokuskan kepada peserta didik yang memiliki masalah ketidakmampuan dalam menerapkan perilaku asertif dalam kehidupan sehari-hari. teknik sosiodrama dapat dipandang tepat karena teknik ini bertujuan untuk memecahakan masalah permasalahan sosial, interaksi sosial, kenakalan remaja, permasalahan dengan latar belakang keluarga dengan cara kelompok.

Melalui teknik sosiodrama peserta didik dilatih untuk mengutarakan pemikirannya, belajar untuk menghargai pendapat orang lain, berkomunikasi secara terbuka, berani mengungkapkan pendapatnya kepada orang lain (Aji Taufiq Pambudi, Supriyono, 2016). Salah satu teknik yang dapat digunakan untuk melatih keterampilan dalam berinteraksi sosial adalah role-play atau bermain peran. Roleplay merupakan teknik dalam pembelajaran yang dapat juga diterapkan dalam konteks pelayanan bimbingan, dengan cara memerankan situasi-situasi yang paralel (sama) dengan kehidupan nyata atau yang sebenarnya, digunakan untuk mengembangkan keterampilan hubungan antar manusia. Melalui permainan peranan, anggota kelompok atau siswa belajar melalui model yang ditunjukkan oleh para pemain. Para siswa juga mengembangkan pemahaman dan ketermapilan dalam berinteraksi sosial (Ella Faridati Zen, Muslihati, Dini HIdayaturrahman, 2020) 


\section{METODE}

Berdasarkan

penelitian yang berjudul

Perilaku Asertif Peserta

Layanan

Bimbingan permasalahan

"Meningkatkan

didik melalui

Kelompok menggunakan Teknik Sosiodrama (Bermain Peran) di SMAN 1 MALIKU”, maka penelitian ini termasuk dalam penelitian kualitatif, dengan menggunakan metode Deskriptif Kualitatif. Teknik pengumpulan data yang digunakan adalah observasi, wawancara, dan dokumentasi. Observasi, adalah melakukan pengamatan terhadap obyek penelitian. Observasi dapat lakukan dengan dua cara yaitu pertama observasi langsung dan observasi tidak langsung. Dalam penelitian ini teknik observasi yang dilaksanakan adalah observasi langsung. Peneliti mengamati secara langsung pelaksanaan sosiodrama serta tingkah laku sehari-hari yang ditimbulkan setelah pelaksanaan sosiodrama.

Untuk lebih memperjelas pengambilan data dilakukan dengan wawancara. Dalam wawancara dilakukan dengan dua cara yaitu wawancara bebas dan terprogram. Wawancara bebas dilakukan terhadap peserta didik yang tergabung dalam kelompok sosiodrama untuk memperoleh data yang sifatnya umum. Pada wawancara bebas berguna untuk menjalin keakraban dan keterbukaan serta tujuan penelitian.Pada saat wawancara berlangsung juga dilakukan pencatatan serta rekaman audio visual. Maksud rekaman agar setelah wawancara tidak ada data yang terlewatkan. Wawancara terprogram dilakukan untuk menggali data yang benar-benar diperlukan dalam penelitian. Untuk wawancara terprogram peneliti telah menyiapkan sejumlah daftar pertanyaan yang meliputi karakteristik sikap asertif yang dimiliki peserta didik, contoh kasus dalam kehidupan sehari-hari yang berkaitan dengan pengambilan sikap asertif sebelum mengikuti sosiodrama, perasaan yang ditimbulkan setelah mengikuti sosiodrama,

perubahan sikap yang terjadi setelah mengikuti sosiodrama.

Dalam penelitian kualitatif peran dokumentasi sangat besar, data dari dokumentasi berguna untuk membantu menampilkan kembali beberapa data yang mungkin belum dapat diperoleh. Beberapa catatan anekdot dan rekaman konseling diperlukan untuk membantu dalam mengalisis data penelitian. Dalam penelitian ini, validitas data menggunakan trianggulasi sumber yang berarti dalam penelitian ini membandingkan dan mengecek balik derajat kepercayaan suatu informasi yang diperoleh melalui waktu dan alat yang berbeda dengan jalan (1) Membandingkan data hasil pengamatan dengan data hasil wawancara, (2) Membandingkan apa yang dikatakan orang di depan umum dengan apa yang dikatakan secara pribadi, (3) Membandingkan keadaan dan persepsi seseorang dengan berbagi pendapat dan pandangan

\section{HASIL DAN PEMBAHASAN}

Cawood (1997) menyatakan perilaku asertif yaitu ekspresi yang langsung, jujur, dan pada tempatnya dari pikiran, perasaan, kebutuhan, atau hak-hak peserta didik tanpa kecemasan yang tidak beralasan. Langsung berarti perilaku siswa dapat menyampaikan pesan di-sampaikan dengan lugas dan wajar, serta tidak menghakimi siswa lain. Jujur berarti berperilaku menunjukkan semua isyarat pesan cocok artinya kata-kata, gerak-gerik, perasaan semuanya mengatakan hal yang sama. Sedangkan pada tempatnya berarti peserta didik dapat mempertahankan hakhak dan perasaan-perasaan peserta didik lain maupun dirinya sendiri, waktu dan tempatnya. Dengan memiliki perilaku asertif, pesera didik lebih mudah mengekpresikan diri, terbuka secara sosial dan emosional, mencapai tujuan tanpa menghancurkan orang lain, bertanggung jawab, dan berani mengambil keputusan tanpa rasa cemas. 
Syamsudin (1980) memberikan penjelasan bahwa Bimbingan Kelompok Teknik Sosiodrama adalah salah satu bentuk bimbingan kelompok yang dipergunakan untuk memecahkan masalah sosial yaitu menggunakan kegiatan bermain peran. Romlah (2006) menerangkan bahwa sosiodrama adalah permainan peranan yang ditujukan untuk memecahkan suatu masalah sosial yang timbul dalam hubungan antar manusia. Berdasarkan beberapa penjelasan di atas dapat disimpulkan bahwa sosiodrama adalah suatu teknik bimbingan kelompok dengan cara bermain peran, subjek memerankan suatu peranan tertentu tentang hal-hal yang berkaitan dengan masalah sosial yang dialami. Melalui sosiodrama diharapkan peserta didik mampu menghayati dan menghargai perasaan orang lain, berbagi tanggung jawab, mampu mengambil keputusan dan melatih siswa untuk berpikir dan memecahkan masalah.

Teknik sosiodrama dapat digunakan untuk melatih keterampilan-keterampilan hidup, salah satunya adalah keterampilan berkomunikasi menyampaikan sesuatu yang dipikirkan dan dirasakan dengan cara membimbing siswa untuk mempraktikkan peristiwa-peristiwa dalam hubungan sosial yang dikemas dalam bentuk naskah sosiodrama. Melalui teknik sosiodrama ini guru dapat mengajarkan cara-cara bertingkah laku yang berkualitas khususnya berkaitan dengan masalah sosial dan hubungan antar sebaya sehingga melalui teknik sosiodrama, peserta didik memerankan suatu peran yang sesuai dengan naskah yang telah disusun. Berdasarkan suatu peranan tersebut diharapkan peserta didik berani memunculkan keputusan, mengungkapkan perasaan dan isi hati apa adanya.

Sebelum memutuskan untuk mengambil layanan bimbingan kelompok menggunakan teknik sosiodrama dalam meningkatkan perilaku asertif peserta didik, konselor melakukan survey terhadap peserta didik yang mengalami masalah yang sama, dimulai dari tahapan layanan bimbingan klasikal dengan tema "Pentingnya perilaku asertif dalam kehidupan sehari". Setelah pelaksanaan layanan bimbingan klasikal tersebut ada beberapa peserta didik yang melaksanakan layanan konseling individu secara sukarela, karena merasa bahwa dirinya merasakan dampak dari ketidakmampuan untuk berperilaku asertif dalam kehidupan sehari-hari.

Berdasarkan pengamatan pada pelaksanaan sosiodrama pertama menunjukkan bahwa peserta didik memiliki kemampuan yang cukup baik dalam mendengarkan instruksi peneliti. Kegiatan sosiodrama berjalan dengan cukup baik, hal ini ditunjukkan dengan keaktifan peserta dalam kegiatan, ketepatan memperagakan tokoh-tokoh yang diperankan dalam skenario. Beberapa peserta dapat mengungkapkan pendapatnya dengan baik, sedangkan beberapa peserta yang lain ada yang masih malu-malu dalam memerankan naskah sosiodrama yang sudah diberikan. Saat pelaksanaan refleksi sosiodrama pertama, sebagian besar peserta didik masih malu-malu mengungkapkan perasaannya setelah memerankan tokoh saat sosiodrama.

Berdasarkan

pengamatan sosiodrama kedua menunjukkan bahwa peserta didik memiliki kemampuan yang baik dalam mendengarkan instruksi peneliti. Kegiatan sosiodrama berjalan dengan baik, hal ini ditunjukkan dengan keaktifan peserta dalam mengikuti kegiatan, keaktifan berdiskusi dalam mengembangkan naskah sosiodrama sebelum memerankan, ketepatan memperagakan tokoh-tokoh yang diperankan dalam skenario. Hampir semua peserta dapat mengungkapkan pendapatnya dengan baik dan dapat memperagakan tokoh yang diperankannya dengan baik. Hampir semua peserta didik mampu mengungkapkan refleksi dengan tegas dan berani. 
Berdasarkan hasil wawancara bebas ada 4 dari 8 peserta didik masih belum terbiasa memerankan tokoh dalam sebuah drama. Peserta didik merasa asing dengan teknik sosiodrama karena belum pernah melaksanakan sosiodrama, namun peserta didik memiliki keinginan untuk mencoba hal baru tersebut dan berharap bahwa nanti setelah mengikuti kegiatan sosiodrama peserta didik dapat mengubah perilaku pasif dan tidak berdaya yang selama ini masih mereka lakukan dalam kehidupan seharihari. Berdasarkan hasil wawancara terpogram menunjukkan bahwa karakteristik sikap asertif yang dimiliki peserta didik antara lain meminta pertolongan pada orang lain pada saat membutuhkan pertolongan, memandang wajah orang yang diajak bicara pada saat berbicara dengannya, sering bertanya pada orang lain pada saat sedang bingung.

Sedangkan karakteristik perilaku asertif yang tidak dimiliki peserta didik antara lain mampu dan terbiasa mengekspresikan pikiran dan perasaan pada orang lain, pada saat berbeda pendapat dengan orang lain, mampu mengungkapkan pendapatnya secara jujur dan terbuka, pada saat tidak ingin melakukan sesuatu pekerjaan mampu berkata tidak. Contoh kasus dalam kehidupan sehari-hari yang berkaitan dengan pengambilan sikap asertif sebelum mengikuti sosiodrama antara lain takut salah ketika mengungkapkan pendapat saat diskusi kelompok di dalam kegiatan pembelajaran, takut mengungkapkan hal-hal yang tidak disetujui dalam kegiatan organisasi, sulit menolak ajakan teman untuk melakukan suatu kegiatan yang mengganggu kegiatan belajar di rumah, sulit mengatakan tidak jika ada teman yang ingin pinjam uang. Perasaan yang ditimbulkan setelah mengikuti sosiodrama antara lain merasa bahagia karena mengetahui cara menerapkan perilaku asertif dalam kehidupan sehari-hari dengan mempraktekkan latihan secara langsung melalui sosiodrama, merasa tergugah untuk melakukan perubahan tingkah laku sesuai dengan tokoh yang dia perankan maupun sesuai tokoh yang orang lain perankan.

Perubahan sikap yang terjadi setelah mengikuti sosiodrama adalah sebagian besar peserta didik mampu menerapkan perilaku asertif dalam kehidupan sehari-hari terutama dalam lingkungan sosial teman sebayanya, sehingga peserta didik merasakan manfaat dari perubahan tingkah lakunya, misalkan ada perubahan beberapa nilai karena peserta didik dapat mengumpulkan tugas tepat waktu dan dapat belajar dengan cukup, rasa percaya dalam dirinya meningkat, peserta didik lebih peka dalam memahami apa yang diinginkan oleh dirinya sendiri dan apa yang tidak diinginkan oleh dirinya, apa yang bermanfaat bagi dirinya sendiri dan apa yang tidak bermanfaat. Selain itu peserta didik lebih aktif menyuarakan pendapat ketika rapat organisasi, dan mampu untuk berkata tidak apabila tidak setuju dengan hal-hal yang dibicarakan ketika rapat dengan mempertimbangkan perasaan teman sebayanya.

Tidak semua aspek perilaku asertif mengalami peningkatan secara signifikan. Aspek perilaku asertif yang sangat menonjol peningkatannya dari rata-rata peserta didik ialah ekspresif dalam mengungkapkan pendapat. Hal ini di tunjukkan dengan peningkatan intensitas komunikasi peserta didik yang semakin terarah ketika diskusi evaluasi dan ketika diluar kegiatan sosiodrama. Selain itu, mereka sudah tidak malu atau sungkan ketika hendak mengekspresikan perasaan negatif mereka namun tetap tidak dengan menyakiti dan menyinggung orang lain.

Menurut Corey (2010) bahwa fokus latihan asertif adalah mempraktekkan melalui permainan peran, kecakapankecakapan bergaul yang baru diperoleh sehingga individu-individu diharapkan mampu mengatasi ketidak memadainya dan belajar bagaimana mengungkapkan 
perasaan-perasaan dan pikiran-pikiran mereka secara lebih terbuka disertai keyakinan bahwa mereka berhak menunjukkan reaksi-reaksi yang terbuka itu. Dengan bimbingan kelompok teknik sosiodrama siswa dapat belajar bagaimana terlibat aktif dalam dinamika kelompok, berpendapat dengan jujur dan terbuka, menghargai pendapat oranglain, tidak memaksakan kehendak dan menyampaikan pendapatnya, isi hatinya, keinginannya dengan cara-cara yang baik. Hal-hal tersebut dapat melatih peserta didik berperilaku asertif.

Berdasarkan penjelasan diatas dapat disimpulkan bahwa teknik sosiodrama tepat digunakan untuk melatih ketrampilan yang dibutuhkan dalam pergaulan dengan sesama manusia atau teman sebaya.Salah satunya adalah ketrampilan berkomunikasi secara jujur, terbuka, bertanggungjawab dan menghargai oranglain. Melalui teknik sosiodrama, Konselor mengajarkan perilaku yang berkualitas dalam berhubungan dengan teman sebaya. Peserta didik yang ditunjuk memerankan peran yang telah disusun dalam naskah sosiodrama dapat memahami cara-cara berkomunikasi yang baik, jujur, terbuka, bertanggungjawab dan menghargai orang lain. Dengan demikian peserta didik memiliki keterampilan sosial yang dibutuhkannya dalam pergaulan. Keterampilan sosial dalam pertumbuhan sosial remaja sangat penting, keterampilan sosial mencakup kemampuan untuk membangun pertemanan, bertemu dan berbau dengan lingkungan, berkomunikasi serta mempertahankan hubungan pertemanan yang sudah dibangun.

\section{KESIMPULAN}

Sesuai dengan hasil analisis triangulasi data pada Penelitian Kualitatif Deskriptif menggunakan bimbingan kelompok teknik sosiodrama menunjukkan peningkatan perilaku asertif pada masingmasing subyek. Hal tersebut menunjukkan perilaku asertif yang rendah dapat meningkat secara signifikan jika diberikan tindakan yang tepat. Tindakan yang dilakukan konselor adalah melaksanakan bimbingan kelompok teknik sosiodrama. Melalui sosiodrama, siswa dapat secara langsung merasakan manfaat layanan yaitu dapat mempraktekkan cara berperilaku asertif sehingga ketrampilan tersebut dapat diterapkan dalam kehidupan sehari-hari. Keberhasilan layanan bimbingan kelompok teknik sosiodrama menunjukkan bahwa sosiodrama tepat digunakan dalam meningkatkan perilaku asertif siswa.

\section{DAFTAR PUSTAKA}

Arliani, Lina. (2014). Bimbingan Kelompok Teknik Sosiodrama Untuk Meningkatkan Perilaku Asertif Antar Sebaya Siswa Kelas IX SMP Negeri 1 Nguter Tahun Pelajaran 2013/2014. Skripsi: UNS

Corey, Gerald. (2010). Teori dan Praktik Konseling \& Psikoterapi. Bandung: Refika Aditama

Romlah, Tatik.(2001). Teori dan Praktik Bimbingan Kelompok. Malang: Universitas Negeri Malang

Rujiati. (2014). Perilaku Asertif dalam Upaya Mewujudkan Keluarga Harmonis. Skripsi. UIN Sunan Kalijogo Yogyakarta

Sari, N. W. 2014. Pengaruh Teknik Sosiodrama Untuk Meningkatkan Perilaku Asertif Siswa (Jurnal Bimbingan Kelompok), http://jurnal.fkip.unila.ac.id/, diakses 3 April 2018.

Setyowati, P. A. 2014. Meningkatkan Perilaku Asertif Siswa Kelas X SMA Kartika III-I Banyu Biru Melalui Layanan Bimbingan Kelompok (Jurnal Bimbingan Konseling),http://jurnal.uksw.edu, diakses 4 April 2018. 
Jurnal Inovasi BK,Volume 2, Nomor 1 Juni 2020

Herman, H. (2017). Pengaruh Latihan Keteramplan Asertif terhadap Pencegahan Perilaku Bullying. Padang: Universitas Andalas.

Keliat, S.A. (2012). Latihan Asertif dalam Mencegah Bulliying pada Remaja. Jakarta : Universitas Indonesia.

Esti, T. \& Nursalim, M. (2010). Penerapan Latihan Asertif untuk Meningkatkan Ketrampilan Komunikasi Interpersonal Siswa. Jurnal Psikologi Pendidikan dan Bimbingan. 11

Hervita, W. (2005). Pengaruh Pelatihan Pengenalan Kepercayaan Diri Mahasiswa. Yogyakarta: Universitas Islam Indonesia (Skripsi).

A'Yuni, Q. (2010). Perbedaan Tingkat Asertivitas Antara Siswa Dari Keluarga Lengkap Dengan Siswa Dari Keluarga Single Parent. Diperoleh dari http://lib.uinmalang.ac.id/? $\mathrm{mod}=$ th_detail\&id $=06$ 410098. 